\title{
Hubungan Antara Pola Asuh Orang Tua dengan Motivasi Belajar Matematika Siswa
}

\author{
Ayu Pradnya Wulandari ${ }^{1}$, Ndara T Renda ${ }^{2}$ \\ ${ }^{12}$ Prodi Pendidikan Guru Sekolah Dasar, \\ Universitas Pendidikan Ganesha \\ Email: ayupradnyawulandari99@gmail.com ${ }^{1}$, ndara.renda@yahoo.com $^{2}$
}

\begin{abstract}
Abstrak
Permasalahan dalam penelitian ini di antaranya 1) Pola asuh yang tidak sesuai dengan perkembangan anak dan 2) siswa yang memiliki motivasi belajar rmatematika rendah. Tujuan penelitian ini untuk mengetahui hubungan yang signifikan antara pola asuh orang tua dengan motivasi belajar matematika siswa kelas IV SD. Pada penelitian ini rancangan yang digunakan adalah rancangan penelitian Expost Facto. Penelitian expost facto adalah penelitian yang terjadi secara alami tanpa adanya kontrol variabel (objek) yang akan diteliti. Populasi pada penelitian ini adalah kelas IV SD yang berjumlah 138 siswa. Sampel dalam penelitian ini berjumlah 120 siswa. Pengambilan sampel menggunakan teknik proposional random sampling. Metode pengumpulan data dalam penelitian ini menggunakan metode non-tes yaitu kuisioner. Kuisioner yang digunakan berisi 25 butir pernyataan. Data yang diperoleh di analisis menggunakan statistik deskriptif dan statistik inferensial. Analisis statistik deskriptif yang digunakan meliputi mean (M) dan standar deviasi (SD) dan analisis statistik inferensial yang digunakan meliputi 1) uji normalitas (chi-square), 2) uji linieritas, 3) uji hipotesis (korelasi product moment). Hasil penelitian menunjukan hubungan antara pola asuh orang tua dengan motivasi belajar matematika siswa kelas IV SD sebesar 0.95 tergolong sangat kuat. Hasil analisis product moment diperoleh harga $r x y$ hitung $(0.95)>r x y$ tabel $(0.195)$. Dengan demikian dapat disimpulkan bahwa terdapat hubungan yang signifikan antara pola asuh orang tua dengan motivasi belajar matematika siswa kelas IV SD. Jadi, pola asuh orang tua yang tepat dan sesuai dengan perkembangan anak akan membantu meningkatkan motivasi belajar anak.
\end{abstract}

Kata kunci: Pola Asuh Orang Tua, Motivasi Belajar Matematika

\begin{abstract}
The problems in this study include 1) Children parenting pattern are not in accordance with the child development and, 2) students motivation studying on match of low. The research has purpose to know the significant relation among the children parenting pattern and the motivation in studying match of students grade IV. This research which naturally happened without needing any variables control (object) to researched. The objects of population of this research are elementary school students grade IV amount 138 students. Which it's sample is totally 120 students. During taking the sample in the research, the technique use was propotional random sampling. The method of collecting data in this research using non writing method or quisioner. The quisioner that used containing 25 questions. Based on analysis, the data were obtained using the descriptive statistic analysis was used containing 1) Normality test (chi-square), 2) Linierity test, 3) Hypotesis test (product moment correlation). The result of the research shows the relationship between the children parenting patern and motivation studying match of students grade IV Gugus III Kecamatan Susut in school year 2019/2020 in the amount of 0.95 this may include strong category. The result of product moment analysis is obtained by price $r x y_{\text {hitung }}$ $(0.95)>r x y$ tabel $(0.195)$. The conclusion of the research based on the data above is there a significant relation among the children parenting patern and motivation in studying match of students grade IV. Children parenting pattern that are right and in accordance with the childs development will help increase chidrens learning motivation.
\end{abstract}

Keyword: Children Parenting Pattern and Motivation Studying Match.

${ }^{*}$ Corresponding author.

Received 20 April 2020, Accepted 20 Juni 2020; Available online 5 Juli 2020 (C) 2020 MI All Rights Reserved 


\section{Pendahuluan}

Perkembangan pesat era globalisasi saat ini sangat mempengaruhi kehidupan manusia yang semakin meluas, meningkat, sehingga tuntutan hidup juga semakin tinggi. Sebagai akibat dari perkembangan tersebut, pendidikan harus mampu berpijak pada masa kini dan berorientasi pada masa depan. Pendidikan merupakan tonggak utama dalam membantu peningkatkan SDM yang memiliki pandangan yang luas sehingga mampu menghadapi tantangan masa kini dan masa depan. Pendidikan mempunyai peranan yang tinggi dalam membangun sumber daya manusia yang unggul. Sumber daya manusia yang unggul tercipta karena adanya pendidikan yang berkualitas.

Peranan pendidikan tertuang dalam Pembukaan UUD 1945 Alenia ke-4 Undang-Undang No. 20 Tahun 2003 Pasal 3 tentang sidiknas. Sejalan dengan tujuan pendidikan tersebut, untuk mencapainya tentu harus ada kerjasama yang baik dari berbagai pihak. Pihak yang dimaksud adalah keluarga, masyarakat dan sekolah yang dikenal dengan istilah tri pusat pendidikan. Tri pusat pendidikan merupakan penyelenggara pendidikan yang dilakukan oleh tiga pihak secara berhubungan dan saling berkaitan (Wahyudin, 2007:3.13). Khususnya dalam pendidikan keluarga, orang tua mempunyai tugas sebagai pendidik pertama dan utama. Orang tua sebagai pendidik pertama artinya bahwa pendidikan anak dimulai pertama kali di lingkungan keluarga, karena sejak lahir individu di didik dan dibesarkan oleh keluarga. Dikatakan sebagai pendidik utama, karena individu selama menjalani proses kehidupan lebih banyak menghabiskan waktu dalam lingkungkan keluarga, sehingga para orang tua diharapkan menjadi teladan bagi anaknya.

Orang tua sebagai pelaksana pendidikan pertama dan utama perlu disadari sepenuhnya untuk dilaksanakan. Namun pada era saat ini, orang tua terlalu sibuk dengan urusan mereka sendiri tanpa memperhatikan bagaimana perkembangan dan pendidikan anaknya, hal ini menyebabkan ketidakberhasilan anak dalam proses pembelajaran. Kebanyakan orang tua mementingkan waktu untuk bekerja daripada memperhatikan perkembangan anaknya. Sebagai akibat dari hal itu, orang tua akan memberikan pola asuh yang kurang optimal bagi perkembangan pendidikan anak. Menurut Apriastuti (2013:4) "macam-macam cara yang diterapkan oleh orang tua dalam rangka merawat, melatih dan membimbing anaknya dapat di katakan sebagai pola pengasuhan".

Pola asuh orang tua adalah sikap atau cara yang di tunjukan oleh orang tua terhadap anaknya dalam mendidik, menjaga, merawat, dan membimbing anaknya dengan penuh tanggung jawab dalam mencapai proses kedewasaan anak (Budiarnawan 2014). Dalam kegiatan pengasuhan, "orang tua memberikan seluruh perhatian, peraturan, disiplin serta motivasi untuk anaknya" (Djamarah, 2014: 52). Sikap, perilaku dan kebiasaan orang tua akan memberikan motivasi bagi anak untuk meningkatkan kualitas belajarnya. Hal tersebut diperkuat oleh pendapat (Suwatra, dkk: 2009) yang menyatakan bahwa, "kontribusi orang tua patut dilibatkan dalam usaha memelihara dan meningkatkan motivasi belajar siswa". Sehingga dalam hal ini orang tua memiliki kedudukan dan posisi sangat penting yang dapat menentukan pola asuh dalam pelaksanaan pendidikan anak (Wibowo, 2012). Pola asuh sangat perlu ditekankan, karena bagiamanapun dalam proses kehidupan anak pasti akan memerlukan bimbingan maupun arahan. Bimbingan dan arahan itulah yang nantinya akan dapat membangkitkan motivasi belajar anak. Sejalan dengan penelitian yang dilakukan oleh Marisa (2018) yang menunjukan bahwa terdapat hubungan yang signifikan antara pola asuh orang tua dengan motivasi belajar remaja. Motivasi anak untuk belajar tidak terlepas dari lingkungan keluarga. Motivasi belajar anak berkaitan dengan sejauh mana ayah, ibu, dan seluruh anggota keluarga yang lain menunjukan perhatian dan merasa berkepentingan dengan kemajuan belajar anaknya. Keluarga dapat mendorong keinginan siswa untuk belajar sehingga siswa akan memiliki motivasi belajar yang tinggi.

Perlu di sadari bahwa banyak faktor yang mempengaruhi motivasi belajar siswa. Faktor yang mempengaruhi motivasi belajar siswa bisa berasal dari dalam (internal) maupun faktor dari luar (eksternal). Salah satu faktor eksternal yang mempengaruhi motivasi belajar adalah pola asuh orang tua. Siswa yang memiliki motivasi belajar yang unggul akan mempunyai 
dorongan yang kuat dalam melaksanakan kegiatan belajar. Berawal dari kata "motif" itu, maka motivasi dapat diartikan sebagai daya penggerak yang telah aktif (Sardiman, 2007). Motif menjadi aktif pada saat-saat tertentu, terutama bila kebutuhan untuk mencapai tujuan sangat dirasakan/mendesak. Menurut Clayton "motivasi belajar adalah kecenderungan siswa dalam melakukan kegiatan belajar yang di dorong oleh keinginan untuk mencapai keberhasilan dan hasil belajar sebaik mungkin". Jadi, motivasi belajar adalah suatu dorongan atau hasrat yang timbul dari dalam diri untuk melakukan kegiatan belaja guna mencapai tujuan yang diinginkan dalam rangka perubahan perilaku, baik dalam aspek kognitif, afektif, maupun psikomotor. Dengan adanya motivasi siswa akan belajar lebih keras, tekun dan memiliki konsentrasi penuh dalam pembelajaran. Jika motivasi yang dimiliki oleh siswa rendah maka akan berakibat rendahnya hasil yang diperolehnya selama mengikuti kegiatan pembelajaran. Sebaliknya, jika motivasi belajar anak tinggi maka hasil belajar juga akan optimal.

Pada penelitian lain motivasi belajar yang di teliti biasanya tidak spesifik pada satu mata pelajaran melainkan yang di ulas adalah motivasi belajar secara umum. Sedangkan realitas yang ditemukan sekarang ini banyak anak yang mempunyai motivasi belajar rendah dalam mempelajari mata pelajaran-mata pelajaran di sekolah dasar diantaranya mata pelajaran matematika. Hasil penelitian Soedjaji mengemukakan bahwa peserta didik yang ada di sekolah dasar memiliki daya serap untuk mata pelajaran matematika rata-rata hanya sebesar 42\% (Susanto,2013). Selain itu pada penelitian Egok (2016) menjelaskan mengenai hasil survey yang dilakukan oleh International Student Assesment (PISA) tentang system pendidikan dan kapabilitas dari sekolah, ternyata Indonesia berada pada urutan terendah ke2 dalam bidang ilmu matematika. Tidak sedikit siswa yang mengaku tidak suka dengan pembelajaran matematika, dikarenakan pembelajaran yang terkesan menggunakan pemecahan masalah dalam menyelesaikannya.

Matematika merupakan ilmu universal yang membahas tentang teori bilangan, aljabar, penyelidikan, teori peluang dan matematika diskrit maka diperlukan kemapuan berfikir logis, kritis, sistematis dan kreatif (Lestari, 2015). Kata matematika berasal dari bahasa latin. Mathainein atau mathema yang berarti "belajar atau hal yang dipelajari", sedangkan dalam bahasa belanda, matematika disebut wiskunde atau ilmu pasti, yang kesemuanya berkaitan dengan penalaran (Depdiknas dalam Fimansyah, 2015). Unsur utama pekerjaan matematika adalah penalaran deduktif, selain itu matematika juga bekerja melalui penalaran induktif. Karakteristik matematika yang sangat kompleks dan rumit mengakibatkan anak sulit untuk mengerti dan mempelajarinya, sehingga anak yang merasa dirinya tidak mampu menyelesaikan permasalahan matematika kecenderungan akan enggan atau malas untuk belajar. Pada proses pembelajaran matematika, banyak siswa yang terlihat pasif, tidak memiliki semangat dalam belajar, tidak berkonsentrasi, dan bermain-main dengan temannya. Adanya sikap tersebut dalam proses pembelajaran menujukan bahwa siswa memiliki motivasi belajar yang rendah. Motivasi belajar matematika yang dimaksud dalam penelitian ini adalah suatu dorongan atau hasrat yang timbul dalam diri untuk melakukan kegiatan belajar matematika guna mencapai tujuan yang diinginkan dalam rangka perubahan perilaku, baik dalam aspek kognitif, afektif maupun psikomotor.

Proses wawancara dilakukan pada guru dan orang tua yang bersangkutan mengenai keterlibatan orang tua dalam proses belajar siswa di sekolah maupun di rumah, data yang dapat disimpulkan dari hasil wawancara adalah kurangnya keterlibatan orang tua terhadap anaknya dalam proses pembelajaran, orang tua yang menerapkan pola asuh yang kurang sesaui dengan kondisi anak, orang tua yang mengedepankan sikap egois yang akan membuat anak terkekang dan sulit untuk beradaptasi dengan lingkungan belajarnya, dan keikutsertaan orang tua terlihat hanya pada saat penerimaan rapot saja dan sangat jarang ditemukan orang tua mengetahui perkembangan anaknya dalam belajar baik di sekolah maupun di rumah khususnya pada mata pelajaran matematika. Hal tersebut menunjukan bahwa pola asuh orang yang diberikan oleh orang tua pada anaknya kurang optimal.

Selain itu, pada saat observasi proses pembelajaran matematika di kelas banyak permasalahan yang ditemukan. Fakta yang ditemukan pada saat pengamatan pada proses 
pembelajaran di kelas yaitu, siswa bermain-main selama proses pembelajaran, tidak adanya antusias siswa dalam proses pembelajaran dan siswa pasif dalam proses pembelajaran, beberapa siswa tidak membawa buku catatan, dan banyak siswa tidak mengerjakan pekerjaan rumah yang diberikan oleh guru. Hal ini menunjukan bahwa siswa siswa mempunyai motivasi belajar yang rendah.

Untuk melengkapi hasil wawancara dan observasi, maka dilakukan studi dokumen tentang motivasi belajar siswa yang dilihat dari hasil belajarnya. Hasil belajar ini digunakan untuk membuktikan siswa yang memiliki motivasi belajar rendah. Hasil belajar di bawah ini didapatkan dari nilai UTS siswa. Berikut studi dokumen tentang hasil belajar matematika siswa.

Tabel 1 Hasil Belajar Matematika

\begin{tabular}{ccccccc}
\hline No & Nama Sekolah & KKM & $\begin{array}{c}\text { Jumlah } \\
\text { siswa }\end{array}$ & $\begin{array}{c}\text { Jumlah } \\
\text { siswa } \\
\text { yang } \\
\text { mencap } \\
\text { ai KKM }\end{array}$ & $\begin{array}{c}\text { Jumlah } \\
\text { siswa } \\
\text { yang } \\
\text { tidak } \\
\text { mencap } \\
\text { ai KKM }\end{array}$ & $\begin{array}{c}\text { Nilai rata- } \\
\text { rata }\end{array}$ \\
\hline 1 & SDN 1 Sulahan & 70 & 33 & 14 & 19 & 64 \\
\hline 2 & SDN 2 Sulahan & 70 & 28 & 12 & 16 & 63 \\
\hline 3 & SDN 3 Sulahan & 70 & 29 & 13 & 16 & 60 \\
\hline 4 & SDN 4 Sulahan & 70 & 11 & 5 & 6 & 65 \\
\hline 5 & SDN 5 Sulahan & 70 & 14 & 5 & 9 & 60 \\
\hline 6 & SDN 1 Susut & 70 & 23 & 9 & 14 & 63 \\
\hline & Jumlah & & $\mathbf{1 3 8}$ & 53 & 80 & 62,5 \\
\hline & Persentase & & & $38 \%$ & $58 \%$ & - \\
\hline
\end{tabular}

Berdasarkan tabel di atas dapat dilihat bahwa jumlah siswa yang tidak mencapai KKM sebanyak 80 orang $(58 \%)$, berada di atas KKM sebanyak 53 orang $(38 \%)$. Dilihat dari nilai rata-rata siswa baru mencapai 62,5, jika di klasifikasikan ke dalam PAP menurut Agung (2016) masih berada pada kriteria rendah. Oleh karena itu, jika dilihat dari hasil belajar siswa yang rendah maka dapat disimpulkan motivasi belajar matematika siswa SD Gugus III Kecamatan Susut Tahun Pelajaran 2019/2020 dinyatakan rendah. Hasil belajar peserta didik akan meningkat jika orang tua ikut terlibat dalam usaha memelihara dan meningkatkan motivasi belajar siswa. Oleh karena itu orang tua perlu menyadari bahwa pola asuh yang diberikan akan mempengaruhi kondisi anak dalam belajar terutama pada motivasinya.

Berdasarkan data awal tersebut, maka penting untuk diteliti hubungan antara pola asuh orang tua dengan motivasi belajar, sehingga dilakukan penelitian expost facto dengan judul "Hubungan antara Pola Asuh Orang Tua dengan Motivasi Belajar Matematika Siswa Kelas IV SD Gugus III Kecamatan Susut Tahun Pelajaran 2019/2020". Jadi tujuan penelitian ini adalah untuk mengetahui hubungan yang signifikan antara pola asuh orang tua dengan motivasi belajar matematika siswa kelas IV SD Gugus III Kecamatan Susut tahun pelajaran 2019/2020.

\section{Metode}

Penelitian ini dilaksanakan di SD Gugus III Kecamatan Susut yang terdiri dari 6 sekolah dasar yang meliputi SD 1 Sulahan, SD 2 Sulahan, SD 3 Sulahan, SD 4 Sulahan, SD 5 Sulahan dan SD 1 Susut Tahun Pelajaran 2019/2020. Penelitian ini dimulai pada tanggal 3 Maret 2020 sampai tanggal 7 Maret 2020 dengan cara menyebarkan kuisioner di masing-masing sekolah sesuai dengan jadwal yang sudah ditentukan. Rancangan penelitian ini dilakukan di SD Gugus III Kec. Susut Tahun Pelajaran 2019/2020. Pada penelitian ini rancangan yang digunakan 
adalah rancangan penelitian Expost Facto. Penelitian expost facto adalah penelitian yang terjadi secara alami tanpa adanya kontrol variabel (objek) yang akan diteliti.

Populasi dalam penelitian ini adalah seluruh siswa kelas IV SD Gugus III Kecamatan Susut tahun pelajaran 2019/2020 yang berjumlah 138 siswa. SD Gugus III Kecamatan Susut terdiri dari 6 SD. Seluruh populasi tersebut meliputi SDN 1 Sulahan, SDN 2 Sulahan, SDN 3 Sulahan, SDN 4 Sulahan, SDN 5 Sulahan, dan SDN 1 Susut. Penentuan jumlah sampel dari keseluruhan populasi yang ada yaitu sebanyak 138 siswa menggunakan rumus Warwick dan Lininger (1975) diperoleh jumlah sampel akhir penyebaran instrument sebanyak 120 orang atau kisaran $87 \%$. Teknik yang digunakan dalam penelitian ini adalah propsional random sampling. Sampling prososional adalah pengambilan sampel didasarkan atas perimbangan pada tiap kelompok atau sub-kelompok yang terdapat di dalam populasi (Agung, 2014: 84). Berikut dijabarkan sampel penelitian secara lebih rinci.

Tabel 2 Sampel Penelitian

\begin{tabular}{llccc}
\hline No & Nama Sekolah & Populasi & Sampel & $\begin{array}{c}\text { Sampel } \\
\text { (Pembulatan) }\end{array}$ \\
\hline 1 & SD Negeri 1 Sulahan & 33 & 28,71 & 29 \\
\hline 2 & SD Negeri 2 Sulahan & 28 & 24,36 & 24 \\
\hline 3 & SD Negeri 3 Sulahan & 29 & 25,23 & 25 \\
\hline 4 & SD Negeri 4 Sulahan & 11 & 9,57 & 10 \\
\hline 5 & SD Negeri 5 Sulahan & 14 & 12,18 & 12 \\
\hline 6 & SD Negeri 1 Susut & 23 & 20,01 & 20 \\
\hline Jumlah & $\mathbf{2 1 9}$ & $\mathbf{1 2 0 , 0 6}$ & $\mathbf{1 2 0}$ \\
\hline
\end{tabular}

Untuk memperoleh data pola asuh orang tua dan motivasi belajar matematika siswa menggunakan metode non-tes. Metode non-tes yang dipakai adalah angket (kuisoner). "penggunaan angket bertujuan untuk mengumpulkan data hasil penelitian atau data yang menginput tentang latar belakang peseta didik" (Sudijono, 2009: 84). Jumlah kuisioner yang digunakan dalam penelitian ini berjumlah 25 butir pernyataan pada pola asuh orang tua dan 25 butir pernyataan pada motivasi belajar matematika. Angket atau kuisoner yang digunakan dalam penelitian ini akan dinilai dengan menggunakan skala likert. Instrument yang akan digunakan menggunakan lima alternative pilihan jawaban yaitu skor 5 sangat sesuai, skor 4 sesuai, skor 3 kurang sesuai, skor 2 tidak sesuai, dan skor 1 sangat tidak sesuai. Hasil uji dari instrument diantaranya 1) uji vailiditas menggunakan rumus gregrory pada instrument pola asuh orang tua dan motivasi belajar matematika memiliki validitas sangat tinggi, 2) uji validitas butir soal menggunakan product moment pada instrument pola asuh orang tua dan motivasi belajar matematika didapatkan hasil yang dinyatakan valid sebanyak 25 butir soal dan yang tidak valid sebanyak 5 butir soal, dan 3) uji reabilitas menggunakan rumus alpha Cronbach, hasil uji reabilitas instrument motivasi belajar matematika mendapatkanmendapatkan hasil $r_{11}$ (0.855) dapat dinyatakan kuisioner memiliki reabilitas sangat tinggi, sedangkan instrumen pola asuh orang tua mendapatkan hasil yang diperoleh setelah melakukan uji analisis tersebut adalah 0.840 dinyatakan kuisioner memiliki reabilitas sangat tinggi.

Indikator pola asuh orang tua pada kuisioner yang digunakan diperoleh dari teori teori PAR (dalam Wibowo, 2016) yang terdiri dari aspek pola asuh acceptance (menerima) dan pola asuh rejection (menolak). Sedangkan indikator motivasi belajar matematika yang digunakan diperoleh dari teori Hanafiah dan Cucu (2009: 28) yang meliputi, durasi belajar, sikap terhadap belajar, frekuensi belajar, konsistensi terhadap belajar, dan kegigihan dalam belajar, loyalitas dalam belajar, visi dalam belajar dan achiement dalam belajar. Metode analisis data pada penelitian ini menggunakan metode analisis statistic deskriptif dan metode analisis statistic inferensial.

Metode statistisk deskriptif yang digunakan antara lain 1) mencari standar deviasi (SD), 2) mencari mean. Sedangkan metode statistik inferensial yang digunakan antara lain 1) uji 
normalitas (chi-square), 2) uji linieritas (uji-f), 3) uji hipotesis (product moment) dengan kriteria harga $r_{\text {tabel }}$ menggunakan taraf signifikansi 5\% $(0,05)$. Kemudian jika $r_{\text {hitung }} \geq r_{\text {tabel, }}$ maka $H_{0}$ dinyatakan ditolak yang berarti signifikan. Dengan ketentuan nilai $r$ diantara $(-1 \leq r \leq+1)$. Apabila nilai $r=-1$ artinya korelasinya negatif sempurna; $r=0$ artinya tidak ada korelasi; dan $r$ $=1$ berarti korelasinya kuat. Untuk menyatakan besar kecilnya sumbangan variabel $X$ terhadap $\mathrm{Y}$ dapat ditentukan dengan rumus koefisien determinasi sebagai berikut; $\mathrm{KD}=r^{2} \times 100 \%$.

\section{Hasil Dan Pembahasan}

Hasil penelitian motivasi belajar matematika seperti yang sudah dipaparkan sebelumnya, diambil dengan cara melakukan penyebaran kuisioner dengan jumlah pernyataan sebanyak 25 butir dan dihitung dengan skala yang sudah ditentukan. Penyebaran dilakukan pada kelas IV SD Gugus III Kecamatan Susut tahun pelajaran 2019/2020. Deskripsi hasil kuisioner motivasi belajar matematika kelas IV SD Gugus III Kecamatan Susut tahun pelajaran 2019/2020 akan dipaparkan sebagai berikut.

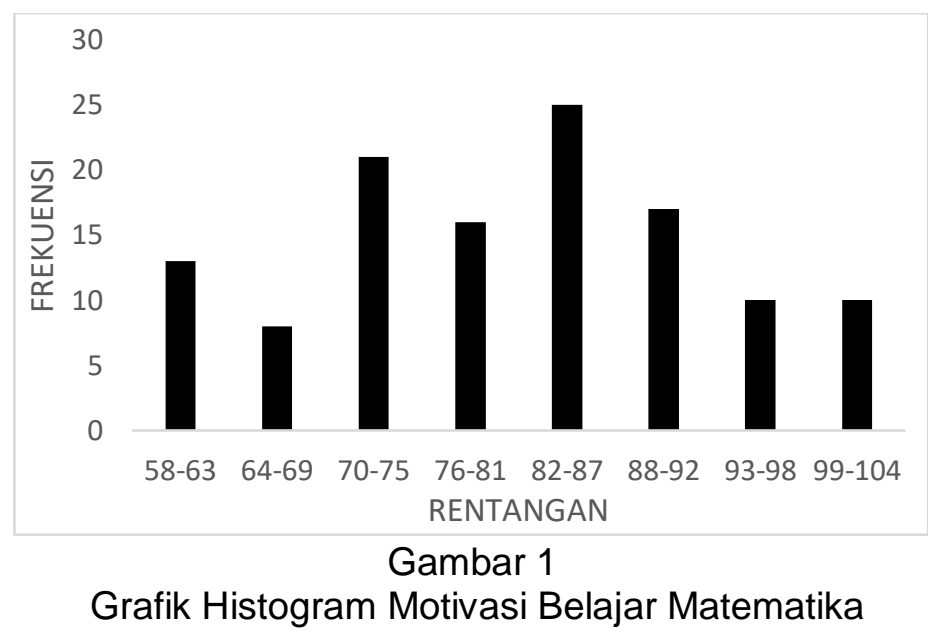

Berdasarkan grafik histogram motivasi belajar matematika dapat diketahui bahwa jika dilihat dari frekuensinya, data motivasi belajar matematika paling tinggi berada pada rentangan skor (82-87) memiliki frekuensi sebanyak 25 dan paling rendah pada rentangan skor (64-69) memiliki frekuensi sebanyak 8. Pada tabel 4.1 rentangan skor (82-87) ini memiliki titik tengah (x) 84,5 sedangkan rentang skor (64-69) memiliki titik tengah (x) yaitu 66,5. Selanjutnya, data motivasi belajar matematika kelas IV SD Gugus III Kecamatan Susut Tahun Pelajaran 2019/2020 ini dapat dikonversikan ke dalam kategori motivasi belajar matematika yang sudah ditentukan ke dalam tabel PAP. Berdasarkan tabel penilaian acuan patokan (PAP), dapat diketahui dari rerata hasil motivasi belajar matematika kelas IV SD Gugus III Kecamatan Susut Tahun Pelajaran $2019 / 2020$ adalah 80,18 . Selanjutnya, rerata $(80,18)$ dikonversikan ke dalam PAP berada pada kategori tinggi.

Hasil dari penelitian variabel pola asuh orang tua kelas IV SD Gugus III Kecamatan Susut Tahun Pelajaran 2019/2020 diperoleh dengan cara penyebaran kusioner. Berdasarkan tabel frekuensi pola asuh orang tua kelas IV SD Gugus III Kecamatan Susut tahun pelajaran 2019/2020 dapat digambarkan dengan grafik histrogram. Berikut gambaran grafik histogram pula asuh orang tua sebagai berikut. 


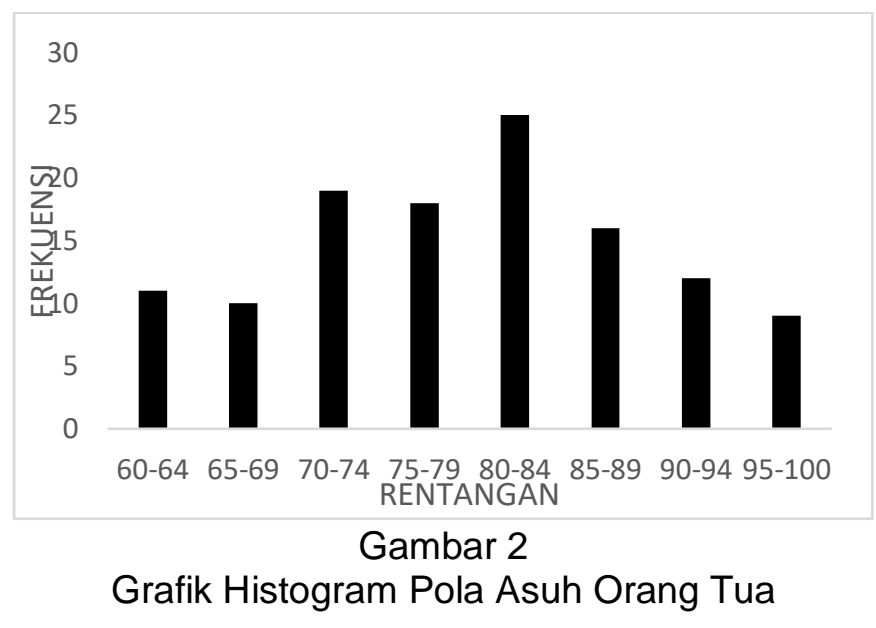

Berdasarkan gambar grafik histogram tentang data pola asuh orang tua kelas IV SD Gugus III Kecamatan Susut tahun pelajaran 2019/2020 jika dilihat dari frekuensinya data pola asuh orang tua yang paling tinggi pada rentangan skor (80-84) yang mempunyai frekuensi sebanyak 25 dan memiliki titik tengah $(x)$ yaitu 82 . Sedangkan data pola asuh orang tua paling rendah pada rentang skor (95-100) mempunyai frekuensi sebanyak 9 dan titik tengah (x) yaitu 97. Selanjutnya, data pola asuh orang tua siswa kelas IV SD Gugus III Kecamatan Susut tahun pelajaran 2019/2020 akan dikonversikan ke dalam kategori tabel PAP. Berdasarkan tabel pedoman konversi skala lima tentang pola asuh orang tua menurut Agung (2016) di atas dapat disimpulkan bahwa dari data pola asuh orang tua didapatkan rerata atau mean sebesar 79.44. Selanjutnya, rerata sebesar 79.44 dikonversikan ke dalam PAP berada pada kategori sedang.

Selanjutnya, dilakukan pengujian asumsi. Pengujian asumsi dimaksudkan untuk mengetahui bahwa data yang didapatkan sudah memenuhi uji persyaratan analisis dengan metode analisis data yang udah sudah ditetapkan. Analisis korelasi product moment yang digunakan untuk menguji hubungan pola asuh orang tua dengan motivasi belajar matematika, memerlukan uji asumsi atau uji persyaratan analisis yakni uji normalitas sebaran data dan uji linieritas. Uji normalitas data motivasi belajar matematika dalam penelitian ini menggunakan chi-square. Data yang didapatkan harga chi-square tabel sebesar 112.39 dan chi square hitung sebesar 145.46 sehingga dapat disimpulkan bahwa $\mathrm{x}^{2}$ hitung $(112.39)<\mathrm{x}^{2}$ tabel (145.46). Karena harga chi-square hitung lebih kecil dari harga chi-square tabel, maka dapat disimpulkan bahwa data hasil penelitian tersebut berdistribusi normal. Sedangkan, uji normalitas dari data pola asuh orang tua mendapatkan harga chi-square tabel sebesar 145.46 dan chi-square hitung sebesar 65.36. Karena harga $x^{2}$ hitung $(65.36)<x^{2}$ tabel (145.46), maka dapat disimpulkan bahwa data hasil penelitian tersebut berdistribusi normal.

Setelah kedua data berdistribusi normal, selenjutnya dilakukan uji linieritas dan arah keberartian ini dimaksudkan untuk mengetahui hubungan antara pola asuh orang tua (variabel bebas) dan motivasi belajar matematika (variabel terikat) bersifat linier. Uji linier dan arah keberatian ini menggunakan bantuan SPPS versi 17.0 for windows. Jika harga $F_{\text {hitung }}$ lebih kecil dari $F_{\text {tabel }}$ pada taraf signifikan $5 \%$ maka kedua variabel memiliki hubungan yang linier dan jika $F_{\text {hitung }}$ lebih besar dari $F_{\text {tabel }}$ maka kedua variabel memiliki hubungan yang berarti. Berdasarkan analisis yang telah dilakukan, didapatkan signifikansi Linearity sebesar $0.000(p<0.05)$ sehingga pola asuh orang tua dengan motivasi belajar matematika memiliki hubungan yang linier. Sedangkan signifikansi Deviation from Linearity sebesar $0.108(p>0.05)$ sehingga pola asuh orang tua dengan motivasi belajar matematika memiliki hubungan yang berarti.

Selanjutnya uji hipotesis, pengujian hipotesis dalam penelitian ini menggunakan teknik korelasi product moment, karena korelasi yang diuji menghubungkan dua variabel yang asimetris. Teknik product moment correlation digunakan untuk menentukan koefisien korelasi antara variabel bebas interval dengan variabel terikat interval (Agung, 2016). Berikut merupakan hasil pengujian hipotesis menggunakan product moment. 
Tabel 3 Hasil Uji Hipotesis

\begin{tabular}{llcclr}
\hline \multicolumn{6}{c}{ Model Summary } \\
\hline Model & $\mathrm{R}$ & $\mathrm{R}$ Square & $\begin{array}{c}\text { Adjusted R } \\
\text { Square }\end{array}$ & Std. Error of the Estimate \\
\hline 1 & $.955^{\mathrm{a}}$ & .912 & .911 & & 2.92141 \\
\hline a. Predictors: (Constant), $\mathrm{Y}$ & & & \\
\hline
\end{tabular}

Hasil pengujian hipotesis mendapatkan harga statistik hasil penelitian pola asuh orang tua dengan motivasi belajar matematika digunakan taraf signifikan $5 \%$ dengan $\mathrm{N}=120$. Berdasarkan taraf siginifikansi 5\% dengan $\mathrm{N}=120$ maka $\mathrm{df}=120-2=198$, sehingga diperoleh harga $r_{x y}$ tabel 0.195 dan harga $r_{x y}$ hitung 0.95. Ini berarti $r_{x y}$ hitung $(0.95)>r_{x y}$ tabel $(0.195)$, sehingga hipotesis nol yang menyatakan tidak terdapat hubungan yang signifkan antara pola asuh orang tua dengan motivasi belajar matematika siswa kelas IV SD Gugus III Kecamatan Susut tahun pelajaran 2019/2020 ditolak. Berdasarkan taraf signifikan 5\%, dapat ditarik kesimpulan bahwa hipotesis alternative yang menyatakan "terdapat hubungan yang signifikan antara pola asuh orang tua dengan motivasi belajar matematika siswa siswa kelas IV SD Gugus III Kecamatan Susut tahun pelajaran 2019/2020 adalah diterima". Sehingga dapat disimpulkan bahwa terdapat hubungan yang signifikan antara pola asuh orang tua dengan motivasi belajar matematika siswa siswa kelas IV SD Gugus III Kecamatan Susut tahun pelajaran 2019/2020.

Berdasarkan tabel interprestasi koefisien korelasi nilai $r$ diatas, diperoleh harga $r_{x y}$ sebesar 0.95, maka dapat dinyatakan pola asuh orang tua dengan motivasi belajar matematika memiliki tingkat hubungan yang sangat kuat. Selanjutnya mencari besaran sumbangan korelasi antara variabel $\mathrm{X}$ terhadap variabel $\mathrm{Y}$ dengan menggunakan rumus koefisien korelasi sebagai berikut.

$$
\begin{aligned}
& \mathrm{KD}=r^{2} \times 100 \% \\
& \mathrm{KD}=0.95^{2} \times 100 \% \\
& \mathrm{KD}=0.90 \times 100 \% \\
& \mathrm{KD}=90 \%
\end{aligned}
$$

Berdasarkan perhitungan koefisien determinasi diatas, didapatkan koefisien determinasi sebesar $90 \%$. Ini berarti variabel pola asuh orang tua $(X)$ secara simultan berpengaruh terhadap motivasi belajar matematika (Y) siswa kelas IV SD Gugus III Kecamatan Susut tahun pelajaran 2019/2020. Selanjutnya sisa dari perhitungan koefisien dapat dicari dengan cara $(90 \%-100 \%=10 \%)$, jadi sisa $10 \%$ ini berarti bahwa dipengaruhi oleh variabel luar selain variabel yang diteliti.

Hasil penelitian berdasarkan pengujian hipotesis di atas dapat disimpulkan bahwa, terdapat hubungan yang signifkan antara pola asuh orang tua dengan motivasi belajar matematika. Hasil pengujian hipotesis pada penelitian ini menggunakan korelasi product moment mendapatkan harga $r_{x y}$ tabel 0.195 dan harga $r_{x y}$ hitung 0.95 . Selanjutnya, berdasarkan perhitungan tersebut juga diperoleh besar tingkat hubungan koefisien korelasi yang sangat kuat. Perhitungan koefisien determinasi sebesar $95 \%$ menunjukan bahwa secara simultan pola asuh orang tua $(\mathrm{X})$ berpengaruh pada motivasi belajar matematika ( $\mathrm{Y}$ ) siswa kelas IV SD Gugus III Kecamatan Susut tahun pelajaran 2019/2020. Jadi jika harga $r_{x y}$ tabel 0.195 dan harga $r_{x y}$ hitung 0.95 , ini berarti $r_{x y}$ hitung $(0.95)>r_{x y}$ tabel $(0.195)$, sehingga dapat di tarik kesimpulan bahwa terdapat hubungan yang signifkan antara pola asuh orang tua dengan motivasi belajar matematika siswa kelas IV SD Gugus III Kecamatan Susut tahun pelajaran 2019/2020. Figur orang tua mempunyai kedudukan yang sangat menentukan proses perkembangan pendidikan anak. Seperti yang dikemukakan oleh Wibowo (2012) bahwa orang tua memiliki kedudukan dan posisi sangat penting untuk menentukan pola asuh dalam pelaksanaan pendidikan anak.

Pola asuh orang tua adalah sikap atau kebiasaan yang di tunjukan oleh orang tua terhadap anaknya dalam mendidik, melindungi, mengurus, dan membimbing anaknya dengan penuh 
tanggung jawab dalam mencapai proses kedewasaan anak. Oleh karena itu, pola pengasuhan orang tua sangat berarti bagi anak yang akan mempengarhui kehidupan anak hingga dewasa kelak. Orang tua harus mengetahui bagaimana karakteristik anaknya sendiri agar, orang tua mampu memberikan pola pengasuhan yang tepat bagi anaknya. Jenis pola asuh yang biasanya diterapkan oleh orang tua adalah pola asuh yang menerima anaknya (acceptance) dan pola asuh yang menolak anaknya (rejection). Menurut Rohner, dkk (dalam Wibowo, 2012: 17) persepsi anak terhadap pola asuh tersebut akan mempengaruhi perkembangan kepribadian individu dan mekanisme yang dikembangkan dalam menghadapi masalah.

Seorang anak yang dibiasakan dengan keadaan keluarga yang saling terbuka, saling menghargai, memberikan perhatian bagi anak, saling menerima dan mau mendengarkan pendapat anggota keluarganya akan memberikan motivasi untuk meningkatkan kualitas belajarnya. Sikap, perilaku dan kebiasaan orang tua tersebut akan berpengaruh terhadap keberhasilan anak di sekolah. Keluarga dapat mendorong keinginan anak untuk belajar sehingga anak akan memiliki motivasi belajar yang tinggi. Menurut Djamarah (2014) untuk membangun motivasi belajar anak, orang tua dapat memulainya dengan memberikan reinforcement pada anak secara terus menerus dan mengurangi secara perlahan, sehinggan motivasi anak akan terbangun dengan sendirinya. Hal ini diperkuat oleh pendapat (Suwatra, dkk: 2009) yang menyatakan bahwa, "keterlibatan orang tua patut diperhitungkan dalam usaha memelihara dan meningkatkan motivasi belajar siswa". Sehingga, semakin tinggi motivasi belajar yang dimiliki maka semakin tinggi pula hasil belajar yang akan diperoleh (Sardiman, 2007).

Dengan adanya motivasi siswa akan belajar lebih keras, tekun dan memiliki konsentrasi penuh dalam pembelajaran. Setiap orang memiliki motivasi belajar yang berbeda-beda di setiap mata pelajaran yang ada di sekolah. Hal ini disebabkan oleh kemampuan anak di setiap mata pelajaran berbeda-beda antara satu anak dengan anak yang lain, sehingga hasil belajarnya pun akan berbeda-beda. Hasil penelitian Budang (2017) menunjukan bahwa terdapat korelasi yang positif antara pola asuh orang tua dengan hasil belajar matematika siswa. Hal ini berarti bahwa pola asuh orang tua sangat berpengaruh terhadap keberhasilan anak dalam belajar. Dalam penelitiannya Budang (2017) juga mengemukakan bahwa "Orang tua banyak yang beranggapan bahwa mata pelajaran matematika dapat digunakan untuk memprediksi keberhasilan seseorang". Motivasi belajar matematika adalah suatu dorongan atau hasrat yang timbul dalam diri untuk melakukan kegiatan belajar matematika guna mencapai tujuan yang diinginkan dalam rangka perubahan perilaku, baik dalam aspek kognitif, afektif maupun psikomotor.

Mata pelajaran matematika merupakan salah satu mata pelajaran yang menggunakan kemampuan berfikir tingkat tinggi (kritis) dan memerlukan tingkat analisis yang tinggi dalam memecahkan permasalahan. Menurut Lestrai (2015) bahwa matematika adalah bidang studi yang mempelajari tentang ide-ide abstrak berisi symbol-simbol yang dipresentasikan dalam bidang, ruang, dan bentuk dengan aturan-aturan yang telah ada dan tidak terlepas dari aktivitas kehidupan manusia sehari-hari sehingga diperlukan kemapuan berfikir logis, kritis, sistematis dan kreatif. Tujuan dari adanya pembelajaran matematika di sekolah agar siswa terampil menggunakan matematika dalam kehidupan sehari-hari. Sehingga, jika seorang siswa berhasil mempelajari matematika dengan baik maka siswa dapat diprediksi akan berhasil juga mempelajari mata pelajaran lain.

Para orang tua sangat mengharapkan hasil belajar matematika anaknya tinggi, maka dari itu diperlukannya dukungan atau dorongan dari orang tua untuk anak agar memiliki motivasi belajar matematika yang tinggi. Jadi, orang tua harus mengetahui bagaimana karakteristik, kebutuhan, dan kondisi anaknya sendiri agar, orang tua mampu memberikan pola asuh yang tepat bagi anaknya sehingga akan meningkatkan motivasi belajar anak. Melalui perhatian inilah orang tua akan merasa berkepentingan dengan kemajuan belajar anaknya, sehingga akan terbangunnya motivasi belajar matematika yang tinggi di dalam diri anak. Berdasarkan pemaparan di atas menunjukan bahwa adanya hubungan yang sangat erat antara pola asuh orang tua dengan motivasi belajar matematika. Dengan demikian pola asuh orang tua memiliki kontribusi yang signifikan terhadap motivasi belajar matematika siswa IV SD Gugus III 
Kecamatan Susut. Penelitian ini juga diperkuat oleh penelitian yang dilakukan oleh Utami (2017) menunjukkan terdapat hubungan yang signifikan antara pola asuh orang tua dengan motivasi belajar pada siswa kelas VIII SMP Negeri 1 Kotabumi Tahun Ajaran 2016/2017. Dengan demikian hal ini berarti bahwa jika orang tua memberikan pola asuh yang tepat dan sesuai dengan perkembangan anak, maka motivasi belajar yang dimiliki oleh anak akan tinggi. Sebaliknya, jika pola asuh orang tua tidak tepat dan tidak sesuai dengan perkembangan anak maka motivasi belajar anak juga akan rendah.

Pola asuh orang tua yang diterapkan oleh orang tua di rumah memberikan pengaruh yang positif terhadap motivasi belajar matematika siswa. Salah satu faktor ekstrinsik yang mempengaruhi motivasi belajar adalah lingkungan keluarga yakni pola asuh orang tuaOrang tua yang menerapkan pola asuh sesuai dengan perkembangan anaknya, maka akan berdampak baik pada motivasi belajar anak. Dengan adanya motivasi belajar, anak akan memiliki daya kosentrasi yang tinggi, tekun dalam belajar, dan akan mempengaruhi anak untuk mencapai target belajar. Anak yang memiliki motivasi belajar yang kuat pada mata pelajaran matematika akan memiliki tingkat keberhasilan belajar yang tinggi. Hal ini disebabkan karena mata pelajaran matematika mempunyai tingkat analisis yang tinggi dalam pemecahannya. Selain pihak keluarga, sekolah mempunyai peranan yang sama untuk membantu meningkatkan motivasi belajar anak. Guru dan pihak orang tua harus berkerja sama untuk membantu meningkatkan motivasi belajar yang ada dalam diri anak. Sehingga dengan demikian orang tua merupakan mitra kerja yang paling tepat dalam pelaksanaan pendidikan anak. Dengan adanya hal tersebut, maka orang tua dengan sekolah secara bersama-sama ikut serta meningkatkan kualitas pendidikan di sekolah.

\section{Simpulan}

Pola asuh orang tua adalah sikap atau cara yang ditunjukan oleh orang tua terhadap anaknya dalam mendidik, menjaga, merawat dan membimbing anaknya dengan penuh tanggung jawab dalam mencapai proses kedewasaan. Sedangkan, motivasi belajar matematika adalah suatu dorongan atau hasrat yang timbul dalam diri untuk melakukan kegiatan belajar matematika guna mencapai tujuan yang diinginkan dalam rangka perubahan perilaku, baik dalam aspek kognitif, afektif maupun psikomotor. Berdasarkan hasil penelitian dan pembahasan diperoleh bahwa terdapat hubungan yang signifikan antara pola asuh orang tua dengan motivasi belajar matematika siswa kelas IV SD Gugus III Kecamatan Susut tahun pelajaran 2019/2020. Saran yang dapat diberikan kepada siswa hendaknya lebih semangat, tekun dan giat belajar serta memiliki motivasi yang tinggi tidak hanya pada mata pelajaran yang disukai namun pada semua mata pelajaran. Kepada guru-guru hendaknya lebih meningkatkan kerjasama dengan orang tua siswa. Kepada orang tua hendaknya mengetahui bagaimana karakteristik, kebutuhan, dan kondisi anak agar para orang tua dapat memberikan pola asuh yang tepat bagi anaknya. Kepada peneliti lain hendaknya agar mengembangkan penelitian yang lain yang berkaitan dengan variabel yang sama maupun variabel yang berbeda.

\section{Daftar Pustaka}

Agung, A. A. Gede. 2014. Metodologi Penelitian Pendidikan. Yogyakarta: Aditya Medika Publishing.

Agung, A. A. Gede. 2016. Statistika Dasar Untuk Pendidikan. Yogyakarta: Deepublish.

Apriastuti, Dwi Anita. "Analisis Tingkat Pendidikan dan Pola Asuh Orang Tua dengan Perkembangan Anak Usia 48-60 bulan. Jurnal Publikasi Kebidanan Akbid YLPP Purwekerto, Volume 4 Nomor 1 (hlm 4) 
Budang, Pinsessius. 2017. "Korelasi Pola Asuh orang Tua dengan Hasil Belajar Matematika Pada Siswa Kelas IV SD Negeri 5 Tengadak. Jurnal Pendidikan Dasar Perkhasa, Volume 3, Nomor 2 (hlm 350)

Budiarnawan, Kt. Agus. 2014. "Hubungan Antara Konsep Diri dan Pola Asuh Orang Tua Terhadap Hasil Belajar IPA Siswa Kelas V SD di Desa Selat. Jurnal PGSD Universitas Pendidikan Ganesha, Volume 2, Nomor 1 (HIm 2-4).

Djamarah, Syiful Bahri. 2014. Pola Asuh Orang Tua dan Komunikasi dalam Keluarga: Upaya Membangun Citra Membentuk Pribadi Anak. Jakarta: PT Rineka Cipta

Egok, Asep S. 2016. "Kemampuan Berpikir Kritis dan Kemandirian belajar dengan Hasil Belajar Matematika”. Jurnal Pendidikan Dasar. Volume 7, Nomor 2 (hlm 187).

Fimansyah, Dani. 2015. "Pengaruh Strategi Pembelajaran dan Minat Belajar terhadap Hasil Belajar Matematika". Jurnal Pendidikan UNSIKA. Volume 3, Nomor 1.

Hanafiah, Nanang dan Cucu. 2009. Konsep Strategi Pembelajaran. Bandung: PT Refika Aditama.

Lestari, Indah. 2015. "Pengaruh Waktu Belajar dan Minat Belajar Terhadap Hasil Belajar Matematika". Jurnal Formatif, Volume 3 Nomor 2 (hlm115).

Marisa Cindy, dkk. 2018. "Hubungan Pola Asuh Orang Tua dengan Motivasi Belajar Remaja. Jurnal Konseling dan Pendidikan. Volume 6, Nomor 1.

Sardiman, A.M. 2007. Interaksi \& Motivasi Belajar Mengajar. Jakarta: PT Raja Grafindo Persada.

Sudijono, Anas. 2009. Pengantar Evaluasi Pendidikan. Jakarta: PT Raja Grafindo Persada.

Susanto, Ahmad. 2013. Teori Belajar \& Pembelajaran di Sekolah Dasar. Jakarta: Kencana Prenada Media Group.

Suwatra, dkk. 2009. Belajar dan Pembelajaran. Singaraja: Universitas Pendidikan Ganesha.

Utami, Nabilah Kartiyasa. 2017. "Hubungan Antara Pola Asuh Orang Tua dengan Motivasi Belajar siswa kelas VIII SMP Negeri 1 Kotabumi Tahun Ajaran 2016/2017". Jurnal Bimbingan dan Konseling, Volume 5 Nomor 5.

Wahyudin, Dinn, dkk. 2007. Pengantar Pendidikan. Jakarta: Univeritas Terbuka.

Wibowo, A. 2012. Pendidikan Karakter Strategi Membangun Karakter Bangsa Berperadaban. Yogyakarta: Pustaka Belajar. 